\title{
Communities and Cultures of Women: A Study of Neighbourhood Groups and Gated Communities in Assam
}

Dr. Syeda Sakira Sahin ${ }^{\dagger}$

\begin{abstract}
The aim of this paper is to tease out the factors and forces that enable women to form communities of women and the circumstances within which they act. In addition, the research aims to observe into their activities to see if there is a germination of gender consciousness even if in a nascent form. Taking off from a historical vantage point of women coming together for various kinds of social and political action, the paper tries to delve into the epistemological dilemma encountered by feminist politics, where the subject of feminist politics i.e., women, is presented as a problematic category. Gender is understood not as a sole defining category but one that exists alongside other constituents of identities intersecting with it like class, caste, race, ethnicity etc. Given such an understanding the paper is based on a micro-level qualitative study conducted in an urban set-up of Guwahati city where two different kinds of locality-based women's communities are taken as case studies, one of which is an all-women local neighbourhood development committee and the other a women's forum within a gated community. The interesting contrasts as well as complexities of the groups in their membership as well their cultures are analysed to raise questions on whether such groups serve patriarchal interests or whether they present themselves as potential sites through which social change towards a more gender-conscious society can be made possible.
\end{abstract}

Key words: Communities of Women, Guwahati, Feminist Epistemology, Social Change, Patriarchy, Assam, India

\footnotetext{
${ }^{\dagger}$ Assistant Professor, Department of Women's Studies, Gauhati University, Guwahati, Emails: sakirasahin@gauhati.ac.in and sakirasahin@gmail.com

(C) 2016 Sahin. This is an Open Access article distributed under the terms of the Creative Commons Attribution License (http://creativecommons.org/licenses/by/2.0), which permits unrestricted use, distribution, and reproduction in any medium, provided the original work is properly cited.
} 


\section{Introduction}

As the title implies, the key purpose of this research is to examine women's communities and cultures as class within neighbourhoods. For this, a micro-level qualitative study was conducted in an urban set-up of Guwahati city, located in Assam. Here, two different kinds of locality-based women's communities were taken as case studies, one of which is an allwomen local neighbourhood development committee and the other is a women's forum within a gated community. Jill Grant and Lindsey Mittelsteadt define gated community as "a housing development on private roads closed to general traffic by a gate across the primary access. The developments may be surrounded by fences, walls, or other natural barriers that further limit public access" (Grant \& Mittelsteadt, 2004, pp. 913-914).

In the Indian context, women, as a collectivity, exercising some amount of agency first appears in accounts of the Nationalist movement. Prior to that the "women's question" emerged during the $19^{\text {th }}$ century social reform period but not as women exercising agency, rather as women on whom or for whom reforms were aimed (Sarkar \& Sarkar, 2007; Chatterjee, 1993). However, women as a group or collective fighting against imperial forces particularly during the Nationalist phase have been sufficiently acknowledged in the pages on the historiography of the freedom struggle in India. What has been considered significant about such an event is not only the display of women's collective agency but the fact that such a move arguably orchestrated by Mahatma Gandhi changed the style and content of Nationalist politics (Bakshi, 1987). From simplistic explanations given by nationalist historians who believed that Mahatma Gandhi was primarily responsible for politicising women by urging them to fight for their own self development (Norvell, 1997; Bala \& Sharma, 1986; Bakshi, 1987), feminist historians of British India are now "...producing serious monographs on how women experienced colonial rule and how it affected their lives as well as how women and the "women's question" affected colonial politics"(Forbes, 2004, p. 4). For instance, Vir Bharat Talwar in his study on the Women's Journals in Hindi, 1910-1920 pointed out how Gandhi took a compromising stand on the women's question by supporting many traditional ideas at the same time as he openly favoured rights for women (Talwar, 1989). There are other studies of the period focusing not on the lives and actions of women per se but the way the colonial discourse constructed them and represented them, which in turn had an effect in the way women imagined themselves and conducted their activities (Forbes, 2004; Sangari \& Vaid, 1989).

Taking off from this historical vantage point of women's collective action in general and women's movement in particular which are much broader programmes, the paper tries to look into smaller women's communities and groups and the cultures they represent in the present day in specific locations. It is observed that women come together in various ways in a social set-up. It is perhaps far easier for women to organise at the community level for developmental work or religious activities than organising for political action. History holds testimony to the fact that women's collective action in the political sphere questioning their own oppressive situations has been possible because women came together for various causes not necessarily feminist; be it temperance, abolitionism, moral reforms, etc., in the West or the National Movement, antiprice rise, anti-corruption agitations, etc., in India. The reasons why women come together may differ, but the potentiality of the social power of communities of women coming together remains unquestionable as the very act of women coming together into groups and collectives poses a direct threat to the traditionally framed isolated roles emerging from familial affiliations that women are subjected to. As pointed out by Radha Kumar the potentiality of such collectives also lies in the fact, which is repeatedly observed, "...where a community expresses consciousness of its own oppression as a community through a protest movement in which women are 
acknowledged to be active; at a certain stage women apply this consciousness to the questions of their own oppression as a sex" (Kumar, 1993, p. 100).

Therefore a micro-level qualitative study into two specific social locations namely, local neighborhood groups and women's groups in gated communities is undertaken to understand if exclusive female institutions, groups, communities, collectives of such kind contain the social power which can usher in changes in women's individual lives as well as in the lives of the community and the society.

The paper begins by delving into the historical evidence for women's collective action in India culminating into the Women's movement as the background understanding of communities of women. The questions that are raised regarding the singularity of a Women's Movement in India given the vast diversity of its people (Sen, 2000; Rajan, 2003), prompts the researcher to engage with the issues of identity and difference among women as argued by post-structuralists. The paper in the subsequent section therefore tries to highlight this theoretical aspect about the category of woman as contingent, which renders the notion of sisterhood, implying bonding and shared identity among women, problematic. It is in the background of this dilemma that the present research is undertaken to understand, if a nascent form of gender consciousness emerges among women when they form collectives or whether woman as a category is too disintegrated to form a kind of 'class' consciousness of their own. A background to history of women's collective action is discussed in the next section.

\section{History of Women's Collective Action: A Background}

End of colonial oppression and India gaining Independence on the one hand ushered in formal gender equality for women as enshrined in the Constitution and on the other hand, also brought forth the realisation of the prevailing gender oppression. This resulted in a vibrant women's movement in the 60s and 70s aimed at fighting this oppression in Indian society, which continues to keep women subservient. The Gandhian-socialists initiated several of the first women's movements in postindependence India. Initially, many of these groups were organised on the basis of various issues like the anti-alcohol agitation in north India, consumer action and anti- corruption agitations in western India and women's trade union also in western India. Interestingly however, neither they nor others looked upon these movements as feminist, nor did they advance any theories of women's oppression (Kumar, 1989). It was the mid-seventies, especially with the publication of the Towards Equality Report of 1975 that much of the research on women's issues and their lived experiences also took place.(Sen S. , 2000; Khullar, 2005; Agnihotri \& Mazumdar, 1995; Menon, 2004).

The late-70s were, in Gandhi and Shah's view, the third wave in the history of the women's movement in India, which unlike the first two waves had a specific feminist focus (Gandhi \& Shah, 1992). The debate in the women's movement in the late-70s and early-80s was about how feminist politics could best be conducted. There was a mushrooming of women's groups in towns and cities, without party affiliations or formal hierarchical structures. The critique from some quarters were that these 'autonomous' groups were urban and middle class and therefore, fails to represent Indian women as a whole (Kumar, 1993; Sen, 2000; Agnihotri \& Mazumdar, 1995). Thus, the larger theoretical questions, as to what it means to be a woman and the issue of identity within feminist politics, fore-grounded itself and came to be debated and written about (Rajan, 2003)

The Western feminist literature by this time was already concerned with such issues. The different strands within feminism also came to be more visible, which is not to say that there were not differences in orientation from the very beginning. However, these were not hard and fast distinctions, there was much overlap and mutual influences as there were differences (Barbara, 1992). It soon became 
obvious that even within the West that the experiences most commonly referred to were effectively white, middle class, heterosexual ones and therefore these universal claims symbolising sisterhood were false. Black women, women of colour and immigrant women in both the USA and in Europe, began to name forms of exclusion and racism in the women's movement of their respective countries (Zinn \& Dill, 1996; Hooks, 1984; Davis, 1981).

According to Indu Agnihotri and Vina Mazumdar, the decades of the Women's Movement in India, which witnessed an upsurge of the movement, that is, the 1980s and $90 \mathrm{~s}$ were also the decades when there were fragmentations and diversities (Agnihotri \& Mazumdar, 1995). The reasons for a fragmented Women's Movement were manyunlike an earlier phase of the colonial period, women no longer saw a common enemy. Even at a time when there was a common enemy, the feminists had not identified it in gender terms nor fought it with a gender agenda. The complexities of Indian culture had not facilitated the analysis of oppression on Indian women on the basis of gender relations unlike that in the West (Kumar, 1993).

Post 70s, therefore, witnessed a shift in the focus and awareness of women's problems in India, emerging from an articulation of diverse interests within the movement (Khullar, 2005; Menon, 1999). What is noteworthy is that most of such differences had emerged due to women's engagement in issues at the more local level. The concept of an overarching movement encompassing within it different identities and aspirations was beginning to give way to more localised and regional women's collective activities (Kumar, 1993; Sen I. , 2005).In a more contemporary phase of the $90 \mathrm{~s}$, there has been an articulation of women's issues among many educated and urban middle class women as well as men. According to Illina Sen "[m]any women from educated backgrounds have come together in groups in a realisation of their strength and potential and have lobbied and protested against the blatant forms of discrimination they face in our society" (Sen I. , 2005, p. 80). Many questions arose alongside the changes that the movement was witnessing. Most important of these was the question of identity and difference. The fragmentation of the movement and articulation of varied interest within it symbolised not only a breakdown of the notion of 'sisterhood' but "...have confused the entire question of whether a women's movement exists or whether it is legitimate in India" (Sen I. , 2005, p. 82). Contentious issues like whether a women's movement exists, who does it represent, what issues it ought to articulate, can it have a narrow feminist focus or a broader social focus have been raised through feminist writings in India (Khullar, 2005). The following section is an attempt to trace some of the theoretical debates that have arisen as a result of these questions.

\section{Women's Movement: Identities and Differences}

It is of little doubt that the category of 'woman' forms the unit of feminist politics and women's movement. However, the assumption that 'woman' is a transhistorical, transcultural and even transregional category is one, which has been continuously, questioned (Cerulo, 1997; Benhabib \& Cornell, 1987). Concerning the matter of women's collectives, Butler in her seminal work "Gender Trouble" contends that "identity categories often presumed to be foundational to feminist politics, that is, deemed necessary to mobilise feminism as an identity politics, simultaneously work to limit and constrain in advance the very cultural possibilities that feminism is supposed to open up. From a political perspective, it seems that it is crucial that feminists attempt to acknowledge and accommodate difference" (Butler, 1990, p. 187). The criticism for the idea of a singular category of women has come from two directions first; that there were intra sexual differences between women, most centrally those of race and sexuality and the second, which challenges the very concept of a coherent identity and a SELF. What it means to be a 'woman' depends on what else one is 
(Spelman, 1982). "If one is a woman, that is surely not all one is, the term fails to be exhaustive...because gender is not always constituted coherently or consistently in different historical contexts and because gender intersects with racial, class, ethnic, sexual and regional modalities of discursively constituted identities. As a result, it becomes impossible to separate out 'gender' from the political and cultural intersections in which it is invariably produced and maintained" (Butler, 1990, p. 6).

Again, deconstructing the category of women as anti-essentialists and socialist feminists have done have been found to be problematic especially while appealing to women's rights. If there is no category of 'women' then who does the subject of feminist politics address (Harding, 1987; Villmoare, 1991). Poststructuralist rejection of the concepts of objectivity and neutrality, insisting that knowledge is a product of perspective and thus always partial, subverts the struggle to end women's oppression (McLaughlin, 2003).

Postmodern/Post-structuralist thought in general challenges uniformity and unified ideas and concepts like those of 'women' or 'feminism'. It therefore undercuts the notion of feminist knowledge as grounded in the experience of women, which is apparently antithetical to the idea of feminism as transformative in practice (Ramazanoglu \& Janet, 2002). The poststructuralist critique of the subject in a way undermines the possibility of agency on the part of the feminist subject, an agency that is essential to politics of resistance and change (Ahmed, 2004). This creates problems for feminist attempts to connect ideas, experience and reality. Feminists critiques of postmodernism also appear apprehensive of the fact that "just when women are beginning to be included in the research process and have been given 'voice', this new view on knowledge building threatens to undermine the success feminism has achieved"(Hesse-Biber \& Leavy, 2007, p. 85)

The counter argument put forward by poststructuralist feminist is that the recognition of the contingency and partiality of knowledge does not undermine our ability to engage in normative debate (McLaughlin, 2003). Nor does post-structuralism necessarily involve a repudiation of agency. Rather many have argued that it is precisely the way in which subjects are constituted in and through multiple contradictory discourses that creates space for agency (Hirschmann N. J., 2003; Mwaka, 2011; Benhabib \& Cornell, 1987; Baxter, 2003). Our subjectivities are never fixed but always in the process of being reconstituted (Burr, 1995). Poststructuralist feminism does not reduce women's oppression to singular or universal factors but rather examines the multiple and shifting dimensions of women's oppression (Jaggar, 1983; Baxter, 2003; Flynn, 2002; Zerilli, 2006). Such a dimension enables the movement to retain its much-needed broad-based character and helps ground feminist politics in collective identities. This understanding of the poststructuralists feminists, which states that the category of 'woman' need not necessarily be homogenous in order for women to mobilise political solidarities amongst themselves underpins the present research, which aims to explore solidarities among women across class barriers.

The above account was necessary in order to contextualise the present study and clarify the theoretical juncture where the study is methodologically placed. The movement for women's emancipation has traversed a vast distance spatially as well as ideologically through critical enquiries and self-reflections, which in turn have helped in entrenching it further. The study draws from the poststructuralist feminists' idea explicated above, of women exercising agency and being able to engage in transformative politics and in bringing about change in gender relations of a society, in spite of their being divided on class, caste and racial lines. Such a theoretical framework seeks to justify the objective of the present research, which aims at exploring collective action by communities of women and emergence of gender consciousness within them. Moreover, the above theoretical exposition also makes it clear that an 
examination of women's communities in specific contextual locations (in this research in Guwahati, Assam) becomes imperative as they provide an alternative framework for looking into women's specific experiences rather than focusing on universal ones. The following section elucidates on the notion of communities of women and its significance for transformative politics.

\section{Communities of Women: The Idea of Sisterhood}

As an idea, the notion of 'Communities of women' is at once exhilarating as it is intriguing. As explicated above, far from being a novel concept the idea of women's solidarity, bonding, and sisterhood are interspersed in history both of the west as well as in India, in various contexts. Yet it is intriguing as the notion of bonding implies a shared identity among women, which in the political sense today, is a hugely contested proposition (Rajan, 2003). Within political movements like the women's movement, a community can be defined as "a process through which they explore, challenge, and validate female identity in a male-dominated society. It can also be described as a process of creating a cohesive, supportive group from a collection of people who, although diverse, share a commitment to work through issues of gender peacefully and non aggressively" (Kramarae \& Spender, 2000, p. 208). At the macro level of women's movements the role that women's collective action can play and the impact that it can have on society is established beyond doubt, however, it is at the micro levels of society that women's lived realities get expressed and communities of women formed at such instances needs careful examination as they emerge as potential sites (here, two women's collectives in Guwahati City) where structured inequalities between the sexes can be questioned, solidarities between women forged, consciousness among women raised and social change made possible.

Although there are some feminists who feel that unity among women is impossible given our differences (Stanley \& Wise, 2000), altogether abandoning the concept of sisterhood would do more harm than good as the movement would lose a powerful expression of political solidarity, which would weaken and diminish it. A mass-based feminist movement to end sexist oppression cannot exist without a united front. Feminist like Bell Hooks have raised the problematic issue of women bonding by contextualising it historically:

Women are enriched when
we bond with one another,
but we cannot develop
sustaining ties on political
solidarity using the model
of sisterhood created by
bourgeoisie women's
liberationists. According to
their analysis, the basis of
bonding was shared
victimisation, hence the
emphasis on common
oppression (Hooks, 1984,
p. 45).

To embrace the victim identity would have meant for many women to completely give up their agency. Women who negotiate their lives in a variety of ways did not only see themselves as victims and therefore found it difficult to enter into a project of women's political solidarity on those lines. They therefore did not find relevance in the movement. Bonding as victims also oversimplified the complexities of women's experiences and did not leave room to confront those complexities. Such type of bonding between women also reflected the male supremacist thinking and sexist ideology, which teaches women that to be female, is to be a victim. Bell Hooks further states:

Women who are exploited and oppressed daily cannot afford to relinquish the belief that they exercise some measure of control, however relative, over their lives. They cannot afford to see themselves solely as victims because 
their survival depends on continued exercise of whatever personal powers they possess. It would be psychologically

demoralising for these women to bond with other women on the basis of shared victimisation. They bond with other women on the basis of shared strengths and resources. This is the women bonding feminists should encourage. It is this type of bonding which is the essence of sisterhood (Hooks, 1984, p. 45).

The idea of communities or collective identity for women has been particularly significant in the feminist movement. It is possible to single out networks of women, shadow communities within 'the community' (like the two women's groups under study), where responsibility for the creation of community and kinship ties and support systems which secure communal social life are often undertaken. Such communities may occur 'naturally' in the course of particular forms of social life. In addition, there has been a growing awareness that all cultures which maintain a sharp division between the sexes, and also some religious traditions generate allfemale groupings which are of great interest to feminism as these are at once sites where the legacy of patriarchal traditions can be handed down from one generation to the next ensuring continued patriarchal domination and also the potential sites where women's selfconsciousness can be raised (Dutta, 2015).

There is no getting away from the fact then that women do come together for a variety of reasons. Women may bond automatically, instantaneously, naturally due to common factors from fighting for their own rights to the cause of the community, nation etc. These groups may be all women in nature but are not necessarily victimised by a common enemy. They may also bond for economic reasons like those that we see in Self-help groups, Angadwadi $^{1}$ workers and/or by virtue of sharing a common skill like weaving, fisherwoman's group, women's sports team etc. or even by virtue of residing in a common locality. These women's groups need not necessarily adhere to a notion of a shared victimisation process, which is what has found more scholarship and have been extensively theorised and debated. The present study therefore, tries to explore these apparently 'innocent' groupings of women to understand if gender consciousness germinates within them. The following section discusses the communities of women in the study area. The present research is based on the methodology of a feminist social enquiry, which is explicated below followed by the discussion on the communities of women in the study area.

\section{Methodology}

Feminist research has played a crucial role in foregrounding critical enquiries into gender, gender relations and society. Feminism and feminist research has been at the forefront of challenging the silencing of women's voices in society and the stereotyping of women which has informed much of traditional research (Hesse-Biber \& Leavy, 2007; Benhabib \& Cornell, 1987). More often than not it has been found that application of traditional theories into questions of gender and women's experience have resulted in exposing the inadequacy in the explanatory power of such theories (Burns \& Walker, 2005). Feminist methodology therfore aims at including the women's perspective into social phenmenon (Sprague \& Kobrynowicz, 2004). Feminist social enquiry or feminist methodology is not just about adding women to what we research and how we research but about acknowledging that every aspect of reality is gendered (Hughes, 2002). This research therefore seeks to locate

\footnotetext{
${ }^{1}$ The word Anganwadi means "courtyard shelter" in Indian languages. They were started by the Indian government in 1975 as part of the Integrated Child Development Services program to combat child hunger and malnutrition. They are classified as 'volunteers' under a government programme (Palriwal \& Neetha, 2010)
} 
itself within a tradition of feminist social enquiry.

Keeping in mind the above, the study is conducted taking women as the unit of study in two specific social locations, namely neighbourhood communities and gated communities. The aim of this paper is to tease out the factors and forces that enable women to form communities and the circumstances within which they act and to observe into their activities to see if there is a gender consciousness if at all in a nascent form. The study is conducted in an urban set-up taking as examples communities of women in local neighbourhood bodies. It is pertinent in this context to take note of the changing urban neighbourhood, which "has altered significantly and necessarily for women because of changes in the nature of city life and in the roles women play" (Schoenberg, 1980, p. S261). The various changes, which have affected urban social life like, work patterns, family structure, lifestyles, population dispersion; technologies have also affected the ways in which women come together in these groups. At the same time, it cannot be discounted that individual characteristics of women do facilitate or inhibit involvement and the nature of engagement of women in communities.

The two specific social locations in the urban space of Guwahati City where the study is undertaken are:

- Neighbourhood Women's Development Committees or Mahila Unnayan Samitis as they are locally known.

These associations/committees are not a new phenomenon as these informal (sometimes formal and registered committees) have always been part of neighbourhood community life in different localities in most big as well as small towns all over Assam. The particular study on Mahila Unnayan Samitis was conducted in the Panjabari area of Guwahati city. Panjabari area of
Guwahati has been a relatively newer area, which has in recent times developed owning to its proximity to various prominent landmarks like the Dispur Secretariat and the Kalashetra a cultural hub and popular tourist destination. For the purpose of the study, two Samitis which were all women groups were identifiedFakruddin Ali Ahmed Nagar Unnayyan Samiti and Juripar Mahila Samiti within that locality. The study was conducted by observing the activities of the Samitis by attending their monthly meetings as well as through personal interviews conducted with the members, particularly the Secretary and the President of the committee.

- Women's Groups within gated communities.

The second site for the study is a gated community in a locality called Uzan Bazar, which lies at the heart of the older part of the city of Guwahati very near to the mighty river Brahmaputra. Gated communities and apartments in the older areas of the City have arisen as a recent phenomenon in order to accommodate the ever-expanding populations. A mushrooming of apartment buildings is often seen as a particular feature in the urban landscape of most 2-tier cities in India. Gated communities are slightly different from the regular apartment buildings in being well guarded and therefore, socially isolated from its surroundings. Unlike the earlier concept of neighbourhoods, the families within the gated communities 
restrict their associations to only those living inside the apartment building hardly mixing up with those families living outside, even when the apartment is located within an old neighbourhood with an existing social network. The Women's Forum of the Gyanashram Welfare Society, a gated community that was identified as the group under study for the research, lies within such an old neighbourhood of Happy Villa, yet the activities of this community suggests a social isolation from the surrounding neighbourhood. For the purpose of the study, interviews were conducted with members of the group and functions organised by them were attended and observed. Interview questions ranged from organisational aspects of the group like membership, kinds of activities undertaken, funds, etc., to more open-ended questions to the interviewee like whether there is family support for such activities, her views on women's issues, motivating factors, etc.

The two social locations and the women's communities within them were identified on the basis of purposive sampling and the researchers ease of access to the community. It must be stated that the study is exploratory in nature and seeks to understand women's groupings and the potentialities they hold without attempting to make any broad generalisations.

Although the communities of women as neighbourhood development committees (unnayan samitis) or within gated communities under study in this research cannot be assumed to have come into being over specific issues like we find in instances where women specifically form part of political and social movements, yet their coming together do shape ideas about women and their social engagements and provides a space for female bonding as against the traditional isolated private space of the home (Dutta, 2015). Study of such specific groupings of women in such a context becomes relevant.

\section{The Study}

\section{Neighbourhood Women Development Committees}

The women living in the different localities of Panjabari area in Guwahati have formed such women's groups with the aim of taking up developmental work in their respective area/ locality. Fakruddin Ali Ahmed Nagar Unniayyan Samiti, Juripar Mahila Samiti, Jyotideepa Mahila Samanya Parishad and Axomi Mahila Samiti are few of the many women's groups active in the different localities of the area. The women members of these groups, each having a total of around 35-40 members, take pride in being part of these groups and in the fact that they are active in the development of their respective localities. The development work mostly comprises building roads, cleaning drains and planting trees on important occasions. The sense of feeling important at being able to be engaged in developmental activities was apparent in most of these women. The inadequate conditions of living, lack of facilities like good roads, clean water supply, etc., were their prime concerns while circumventing the more women-centred problems and issues like health facilities, raising awareness about reproductive health, education of the girl child especially of those living in the neighbouring slum area. The group comprises primarily educated women from middle to upper middle-class backgrounds

A couple of interesting observations are that in all the localities where these groups function there also exist a general unnayyan samiti (or community development group) which supposedly comprises both men and women. Interestingly, the women I interviewed refer to this group as the men's group. The idea of the generic as men is firmly rooted. The women's group thus functions more or less as a shadow 
community to this group. One of the women's group related an incident where the trees they had planted on the roads were uprooted by some miscreants and after they sought help from the 'men's' group they were helped in replanting it and since then the trees have not been touched by mischief mongers. Among the major ventures taken up by them opening up of a sewing machine school for the underprivileged women of the locality from a donation by OIL India and a doll-making workshop are noteworthy. The groups also felicitate students in the locality who pass their board exams annually in order to encourage them.

They also celebrate an annual function day, which is the highlight of their activities where sports, painting competition, cooking competition and the like take place. Besides some of them are also engaged in literary activities mostly writing poems which in turn allows some women to express their hidden talents.

Two of the groups had set up health camps for women, one in which a male doctor of the locality itself was invited to speak on first aid and how women working in the house in the absence of their men should attend to an injured/sick child or elderly. In addition, another in which female nurses were asked to address issues related to women's health.

When enquired whether women in the locality come to them with their problems and do they help resolve these problems - the President of the Samiti who is herself a widowed mother of two daughters replied that the women who come to her with problems like domestic violence, drunkard husband, extra-marital affairs etc. usually belong to the lower income group who although reside in the same locality are not members of the group; the reason being that they are unable to pay the monthly membership fee of 20 , which is their only regular source of fund. She is also unable to deal with most of the problems they come up with because they come to her personally with their problems but when asked to come on the day of the meeting and speak out in front of the Samiti they do not turn up. Solidarity among women of different class and caste groups, which one was eagerly looking for was found missing. The notion of sisterhood, which was on display, was a false notion. The privileged group had no feeling of commonality with the women of poorer background. The groups analysed thus functioned as all women's non-feminist groups.

\section{Gated Community}

The Community under study which goes by the name Gyanashram Welfare Society (henceforth, referred to as the Society) fulfills the criteria of the definition of gated community stated earlier in being an isolated, surrounded and guarded space not only because it is fenced and guarded but also by virtue of being located in a hillock with primary access available only to its residents, who reside in three separate apartment blocks. A total of 45 families reside and form part of the community comprising of both owners and tenants. The apartment blocks were developed only six to seven years ago and are, therefore, a fairly recent development in a much older neighbourhood, which is also a reason for it being isolated from the latter. Like the unnayan samitis, the Society too has a group comprising primarily of all males who look after the general well-being and day-to-day running of the community. The women's group was formed three years ago, as it was felt that the women in the community needed to be "active and involved" (as stated by one respondent). It was learnt from the interaction with the respondents that for most of the apartments the owners were not solely the male members rather both the male and female of the family. Some apartments were in the name of the mother of the male head in the family. Out of the 45 flats, 30 were owned by both men and women or solely by women and the rest 15 were owned only by men. It is not a matter of surprise that in spite of being a community where more number of apartments were female-owned, it is the men who are engaged with the over-all administration and decision making as apartments being owned by women 
is primarily due to the subsidy given to female applicants of property registration, and not necessarily an example of growing gender equality and does not therefore, translate into greater autonomy for women.

The Women's Forum of the Society is exclusively managed by women who are permanent residents of the apartment. There is exclusivity also in terms of non-inclusion of women residents who are tenants, as members of the Forum. The Forum is organised formally with a President, Secretary and Treasurer appointed on a rotational basis; although unlike the Society itself, the Forum is not registered under The Societies Act. A fee of ? 50 per month is collected as membership fee from women members who are 15 in total at present. The function of the Society, unlike that of the neighbourhood development committees is confined within the walls of the gated community. The Women's Forum on the other hand, although a shadow community of the Society, has extended its reach beyond the gated community in terms of its activities. Most of the activities are of the nature of social service like collection and distribution of relief during floods to affected areas, visit to women's homes and children's homes, etc. Other activities like organising cooking competitions for resident women, painting competitions for children of the residents (both owners and tenants) are also held on a regular basis.

The women in the Forum have regular meetings where plan of action for subsequent activities are discussed and appraisal of earlier activities are made. The meetings of the Forum are also occasions for the women to come out of the confines of their homes and spend time in the company of other women. The Society and the Forum are examples of social networks, which can be regarded as extensions of the gender-divided roles within families dictated by patriarchal norms. The Society regularly organises various functions during special occasions like-Independence Day, Republic day, Vishwakarma Puja, Holi, and Diwali, etc. It is observed that during such occasions the
Women's Forum takes it upon itself most of the organisational work, which are but extended household work traditionally done only by women.

A study of the profile of the women residents indicates that most are educated with a middle class upbringing. Out of the 15 women, four were in regular paid employment, two were retired teachers (one of a college in the city, other of a government school) and the rest had never taken up paid employment although one among them was also a qualified non-practising lawyer. Most of the women spoke about supportive families and of husbands who helped in household chores, yet the prevalence of gender division of labour in the individual lives of the women as well as in their community activities were quite conspicuous.

A very interesting feature of gated communities is the fact that there is a large section of service people like drivers, part-time domestic workers, cleaners, etc., who form an extended part of these communities, usually residing in the fringe areas. Most of the households employ part time domestic workers, some of whom work in multiple households within the community. The class distinction between the part-time domestic workers and the women in the gated community was found to be very stark with no effort being made by the Forum to bridge the gap or to engage with the issues of the lower-class women who regularly provide service to the apartments. However, most of the informal talks in the regular meetings of the Forum revolved around the issue of lack or inadequacy of domestic help. What is obvious is a lack of female group consciousness among most the women in the Forum, instead a more dominant display of class-consciousness is observed among them.

Do women constitute an oppressed class in their own right have been a matter of much debate among feminists of various strands from Liberal to Marxists to Socialists. Rather than a 'sex-class' as radical feminist like Ti-Grace Atkinson, Robin Morgan and others would argue, Marxists feminist contend that women are more conscious of and shaped by their 
familial class identity (Hennessy \& Ingraham, 1997; Reed, 1970). "Class, which is more mutable than caste and derives more directly from both economic and social standing, has become one of the most potent idioms of identity, rank, and political power in contemporary India, particularly in urban areas" (Dickey, 2000, p. 464). Therefore, only the parameters of income, material assets, and occupation do not define class standing but class identity can also be derived from among many other signs and sources like education, consumption habits, fashion, and ways of speaking (Dickey, 2000). Class can therefore be regarded as both an economic as well as a cultural context and therefore can ascribe definitive meanings of identity and inspire actions accordingly (Caplan, 1987 ). Caste, on the other hand, is a category that has been most theorised in the Indian context as a category, which has a distinct bearing on the lives of men and women (Chakravarti, 2009). This long-standing academic emphasis on caste alone has been criticised by many scholars who provide competing frames of reference to the scale of purity and pollution that underscore most models of understanding on caste. It is not to contend that caste has become unimportant in influencing the lives of people in India but rather to specify that class provide an equally large distinct hierarchy, source of identity and social stratification in Indian society (Dickey, 2000).

\section{Analysis}

A close observation of the groups studied above points to the glaring fact that women coming together do not automatically translate into their developing a gender consciousness where they would be equipped to question their relative subordinate position in society. If at all, in the present study, most of the women were found to be willing adherents of the patriarchal ideology, taking pride in their differences from men and their gender segregated care-giving and nurturing roles. As is seen many women do not join organised resistance against sexism precisely because sexism has not meant an absolute lack of choices. This finding bears resonance to Hooks (Hooks, 1984, p. 5) who commented:

They may know they are discriminated against on the basis of sex, but they do not equate this with oppression. ... The absence of extreme restrictions leads many women to ignore the areas in which they are exploited or discriminated against; it may even lead them to imagine that no women are oppressed.

The President of one of the group in the Neighbourhood Development Committee apparently is 'empowered'-she runs the family on her own after the death of her husband, has raised two accomplished daughters and has one of them married while the other is studying management in Delhi. She lives alone with few helpers, drives her own car to work in a well-known school in Guwahati where she teaches English. Her personal and her community life reflect the occasionally restructured behaviour which patriarchy allows and which most women negotiate with. Therefore, if and when the women speak about women's oppression it appears that they are speaking not of themselves but for somebody else's oppression. They find it difficult to ignore the differences between their social status and the status of masses of women who face oppression on a daily basis.

The same characteristic of patriarchy not imposing a thoroughgoing oppression on women can on the other hand facilitate women's agency and enable women to act in favour of women's rights. To quote Nancy Hirschmann "social constructivism suggests that the degree to which women live out patriarchal ideology ... is dependent on the ideology's success in creating them concretely"(Hirschmann, 2003, p. 79). "This statement implies that patriarchal ideology may have varying degrees of success in affecting the phenomena themselves and thus may not fully 
construct its subjects" (Friedman, 2006, p. 186). Therefore, the fact that the category of "woman" itself is contingent, poses problems for the conduct of feminist politics at the same time as it facilitates women's agency.

The responses and activities of the women in both the communities also point to the fact that women's conformity to patriarchal ideology in terms of the sphere, within which they operate, is only one of the ways women adopt to retain their privilege and bargaining power in a society dominated by men. Such activities although at times seem to be at the cost of other women or in exclusion of other women are in fact important strategies to retain some amount of power and privilege. It is internalised by most women early on that the patriarchal system "...however restrictive and limited, also amply reward those who learn to accept their defined roles as mothers and wives" (Geetha, 2007, p. 6). According to Patricia Gurin, "...some women derive their social status and prestige entirely from their roles as wives and homemakers, which provide protections, meet dependency needs, and even allow flexibility and control when traditional arrangements work out ideally"(Gurin, 1985, p. 145).

Although in the present study one cannot conclusively say that there was a complete lack of gender consciousness, different studies elucidate why it is difficult for women to develop group consciousness as readily as other subordinate groups/categories (Gurin, 1985). "In the first place, gender inequality, while present and doggedly persistent in some areas, is not as marked as racial inequality, and perception of inequality is more difficult when it is not extreme" (Gurin, 1985, p. 144). Second, in order to gain gender consciousness, the opposing privileged category, that is, the men are not really perceived as opposing, as many a times they jointly share their gains, losses and their fates as members of ethnic/racial groups or economic classes. Lastly, as traditional roles are not entirely without rewards for women, some women have vested interests in the continuation of the social unit (usually of the family) that actually strengthens their unequal status and therefore, they do not feel the need to develop female group affinities (Gurin, 1985).

As far as the Women's Movement and its transformative agenda is concerned, although there is sufficient activity by women for fighting gender discrimination, there is a marked change in the nature of the Movement itself. There is a greater articulation analysis as well as attention to women's issues as more urban and educated women are asserting their rights and identities. Yet "...structurally such groups have often remained circumstantially distant from the actual lives of poor women, even when they have made conscious efforts to articulate their needs" (Sen I. , 2005, p. 81). In the present study, it is observed that on the part of the women's groups, there has been an attempt to reach out and act on behalf of poor women, which can only be termed altruistic rather than based on terms of equality.

\section{Conclusion}

In conclusion, one may say that the transformative agenda of feminist politics can take root only when there is a 'selfconsciousness' about such a shared project by not only women but the society as a whole. The purpose here is not to belie the entire feminist agenda and the women's movement as it appears but rather to pause and look inwards. The women's movement and those concerned with feminist politics have to take note of the increasing articulation by women of various persuasions at the grassroots level. As espoused earlier, these groups of women who function at the grassroots level are the least common denominator for the movement so to speak. Communities of women and the depths and complexities of their linkages will have to be understood if the women's movement wishes to exonerate the charge of it being an elite grouping that is isolationist in its own way. Collective action is an important force that can pressure change in policies and bring about political change. What is difficult is mobilising women to come together but when they already have; they become potential sites 
where such political and social change can take place. The need to join hands is felt ever more deeply lest as stated by Indu Agnihotri and Vina Mazumdar, "we come out with a cri de coeurwe have the movement but they (the other?) have the women" (Agnihotri \& Mazumdar, 1995, p. 1877).

\section{References}

Agnihotri, I., \& Mazumdar, V. (1995). Changing Terms of Political Discourse: Women's Movement in India 1970s-1990s. Economic and Political Weekly .

Ahmed, S. (2004). Differnces that Matter: Feminist Theory and Post modernism. Cambridge: Cambridge University Press.

Bakshi, S. R. (1987). Gandhi and Status of Women . New Delhi: Criterion Publishers.

Bala, U., \& Sharma, A. (1986). Indian Women Freedom Eighters 1857-1947. New Delhi: Manohar Publishers.

Barbara, R. (1992). Feminism and the Women's Movement: Dynamics of Change in Social Movement, Ideology and Activism. New York: Routledge.

Baxter, J. (2003). Positioning Gender in Discourse: A Feminist Methodology. New York: Palgrave Macmillan.

Benhabib, S., \& Cornell, D. (1987). Feminism as Critique: On the Politics of Gender . Minneapolis: University of Minnesota Press.

Burns, D., \& Walker, M. (2005). Feminist Methodologies. In B. Somekh, \& C. Lewin, Research Methods in the Social Sciences (pp. 66-73). London, New Delhi: SAGE Publications Ltd.

Burr, V. (1995). An Introduction to Social Constructionism. London: Routledge Publishers.

Butler, J. (1990). Gender Trouble. New York: Routledge.
Caplan, L. (1987 ). Class and Culture in Urban India: Fundamentalism in a Christian Community. Oxford: Clarendon Press.

Cerulo, K. A. (1997). Identity Construction: New Issues New Directions. Annual Review of Sociology, Vol 23 , 385-409.

Chakravarti, U. (2009). Gendering Caste: Through a Feminist Lens. Kolkata: Stree.

Chatterjee, P. (1993). The Nation and Its Fragments: Colonial and Post Colonial Histories. New Jersey: Princeton University Press.

Davis, A. (1981). Women, Race and Class. London: Women's Press Ltd.

Dickey, S. (2000). Permeable Homes: Domestic Service, Household Space, and the Vulnerability of Class Boundaries in Urban India. American Ethnologist, 27 (2), 462-469.

Dutta, N. (2015). Communities of Women in Assam: Being, Doing and Thinking Together. New Delhi: Routledge.

Flynn, E. A. (2002). Feminism Beyond Modernism. Carbondale and Edwardsville: Southern Illinois University Press.

Forbes, G. (2004). Women in Modern India [New Cambridge History of India IV.2]. Cambridge, UK: Cambridge University Press.

Friedman, M. (2006). Nancy J. Hirschman on the Social Constructio of Women's Freedom. Hypatia , 21 (4), 182-191.

Gandhi, N., \& Shah, N. (1992). The Issues at Stake: Theory and Practice in the Contemporary Women's Movement in India. New Delhi: Kali for Women, .

Geetha, V. (2007). Patriarchy (Theorising Feminism). Kolkata: Stree.

Grant, J., \& Mittelsteadt, L. (2004). Types of Gated Communities. Environment and Planning B: Planning and Design, 31, 913-930. 
Gurin, P. (1985). Women's Gender Consciousness. The Public Opinion Quarterly, Vol. 49 (No. 2), 143-163.

Harding, S. (1987). Introduction: Is there a Feminist Method? In S. Harding, Feminism and Methodology. Milton Keyenes: Open University Press.

Hennessy, R., \& Ingraham, C. (1997). Introduction: Reclaiming Anticapitalist Feminism. In R. Hennessy, \& C. Ingraham, Materialist Feminism: A Reader in Class, Difference, and Women's Lives (pp. 1-16). New York, London: Routledge.

Hesse-Biber, S. N., \& Leavy, P. L. (2007). Feminist Research Practice: A Primer. New Delhi: SAGE Publications India Pvt. Ltd.

Hesse-Biber, S. N., \& Leavy, P. (2006). The Practice of Qualitative Research. Thousand Oaks, CA: SAGE.

Hirschmann, N. J. (2003). The Subject of Liberty: Toward a Feminist Theory of Freedom. New Jersey: Princeton University Press.

Hirschmann, N. J. (2003). The Subject of Liberty:Toward a Feminist Theory of Freedom. Princeton Oxford: Princeton University Press.

Hooks, B. (1984). Feminist Theory from Margin to Center. Boston: South End Press.

Hughes, C. (2002). Key Concepts in Feminist Theory and Research. New Delhi: SAGE Publications India Pvt. Ltd.

Jaggar, A. M. (1983). Feminist Politics and Human Nature. Sussex: The Harvester Press Limited.

Khullar, M. (2005). Introduction: Writing the Women's Movement. In M. Khullar, Writing the women's Movement: A Reader (pp. 1-44). New Delhi: Zubaan.

Kramarae, C., \& Spender, D. (2000). Routledge International Encyclopedia of Women: Global Women's Issues and Knowledge. New York: Routledge.
Kumar, R. (1989). Contemporary Indian Feminism. Feminist Review, No.33 (Autumn ), 20-29.

Kumar, R. (1993). History of Doing. New Delhi: Kali for women.

McLaughlin, J. (2003). Feminist Social and Political Theory: Contemporary Debates and Dialogues. New York: Palgrave Macmillan.

Menon, N. (1999). Introduction. In N. Menon, Gender and Politics in India (pp. 1-36). New Delhi: OUP.

Menon, N. (2004). Recovering Subversion: Feminist Politics Beyond the Law. New Delhi: Orient Longman Pvt. Ltd.

Mwaka, N. M. (2011). A Discourse Analysis of Gender in the Public Health Curriculum in Sub-Saharan Africa. Unpublished Doctoral Thesis.

Norvell, L. (1997). Gandhi and the Indian Women's Movement. Retrieved September 2016, from Electronic British Library Journal: http://www.bl.uk/eblj/1997articles/arti cle2.html

Palriwal, R., \& Neetha, N. (2010). Care Arrangements and Bargains: Anganwadi and Paid Domestic Workers in India. International Labour Review , 149 (4), 511-527.

Rajan, R. S. (2003). The Scandal of the State: Women Law and Citizenship in Postcolonial India. Durham and London: Duke University Press.

Ramazanoglu, C., \& Janet, H. (2002). Feminist Methodology Challenges and Choices. New Delhi: SAGE Publications India Pvt. Ltd.

Reed, E. (1970). Women: Caste, Class or Oppressed Sex. International Socialist Review, 31 (No. 3), 15-41.

Sangari, K., \& Vaid, S. (1989). Recasting Women: Essays in Colonial History. New Delhi: Kali for Women. 
Sarkar, T., \& Sarkar, S. (2007). Women and Social Reform in Modern India. New Delhi: Permanent Black.

Schoenberg, S. P. (1980). Some Trends in the Community Participation of Women in Their Neighborhoods. Signs, Supplement. Women and the American City, Vol. 5 (No. 3), S261-S268.

Sen, I. (2005). A Space Within the Struggle. In M. Khullar, Writing the Women's Movement A Reader (pp. 80-101). New Delhi: Zubaan.

Sen, S. (2000). Toward a Feminist Politics? The Indian Women's Movement in Historical Perspective. The World Bank: Policy Research Report on Gender and Development.

Spelman, E. V. (1982). Woman as Body: Ancient and Contemporary Views. Feminist Studies, , Vol. 8 (No. 1), 109-131.

Sprague, J., \& Kobrynowicz, D. (2004). A Feminist Epistemology. In S. N. HesseBiber, \& M. L. Yaiser, Feminist Perspectives on Social Research (pp. 7898). New York: Oxfoed University Press.

Stanley, L., \& Wise, S. (2000). But the empress has no clothes!Some awkward questions about the 'missing revolution' in feminist theory. Feminist Theory, 261-288.
Talwar, V. B. (1989). Feminist Consciousness in Women's Journal in HIndi, 1910-1920. In K. Sangari, \& S. Vaid, Recasting Women: Essays in Colonial History (pp. 266-305). New Delhi: Kali for Women.

Villmoare, A. H. (1991). Women, Difference, and Rights as Practices: An Interpretive Essay and a Proposal. Law and Society Review, Vol. 25, No. 2 (special issue on gender and socio-legal studies) , 385410.

Zerilli, L. (2006). Feminist Theory and the Canon of Political Thought. In J. S. Dryzek, B. Honig, \& A. (. Phillips, The Oxford Handbook of Political Theory (pp. 106124). London: Oxford University Press.

Zinn, M. B., \& Dill, B. T. (1996). Theorizing Difference from Multiracial Feminism. Feminist Studies , 22 (2), 321-331.

\section{About the Author}

Dr. Syeda Sakira Sahin is an alumna of the prestigious International Visitors Leadership Program (IVLP), US State Department's premier professional exchange program. Currently, she is an Executive Committee member and Joint Secretary of the Indian Association of Women's Studies (IAWS), the national professional body of academicians and practitioners of Women's Studies, for the year 2015-17. She has presented a number of academic papers, both in national as well as international conferences and seminars. 